\section{Imperialism and the Dilemma of Slavery in Eastern Arabia and the Gulf, 1873-1939}

\author{
MATTHEW S. HOPPER*
}

An Ethiopian man named Sunür appeared before the British Consul at Addis Ababa in December 1933 and told a remarkable story. He had just returned to Ethiopia after enduring more than five years of slavery in the Arabian (Persian) Gulf where he had been forced to work as a pearl diver. When he was eleven years old and out tending cattle in the Wallamo region of Ethiopia around 1925, he was seized by kidnappers who took him to Tajura on the Somali coast and shipped him along with fifty other captives to Jedda, where he was sold to a man who took him to Qatar and eventually sold him to a pearl merchant who engaged him as a diver. As Surür explained to the consul, he tried twice to escape from his master. The first time, he fled to the British Residency Agent, "Isa bin 'Abdullatif, in Dubai, who promised to protect him, but then returned him to his master, who severely beat him. Shortly after, he fled to the British agency office in Sharjah, only to find that the Residency Agent was the same 'Isa bin 'Abdullatif, who again returned him to his master, who this time beat him until he was unconscious. Surür finally managed to escape by fleeing to a boat bound for Basra. There, he met some Somali men working as stokers on a British steamer who assisted him in getting to Djibouti by way of Muscat. When he arrived in Djibouti he was interrogated by port officers, and his story was passed on to the British consul at Addis Ababa who interviewed him and forwarded his story to the Political Agent at Muscat. ${ }^{1}$

No one in the Persian Gulf Administration would have been surprised to hear Surur's story or to learn that the slave trade and the institution of slavery endured in the Gulf into the 1930 s. $^{2}$ Despite the fiery antislavery rhetoric of the nineteenth century and the aggressive, highly-publicized antislavery patrols of the Royal Navy in the Western Indian Ocean. British antislavery measures diminished rapidly after 1890 . The slave trade from East Africa to the Gulf persisted, a fact which was evidenced by the Gulf Political Resident's discovery in 1900 that at least 1,000 enslaved Africans were still annually imported to the Omani port of Sur, the capture by Portuguese forces of more than 100 men from Sur shipping more than 700 enslaved Africans (mostly
Makua) from the Mozambique coast in 1902, and the intermittent arrival at British agencies and ships of newly-imported slaves seeking manumission. What changed in the late nineteenth century was not the slave trade into the Gulf or the institution of slavery, but British responses to the problem. ${ }^{3}$

The persistence of the slave trade decades after it was officially abolished by treaties, particularly the treaties with the Sultans of Zanzibar and Muscat in 1873 and increased naval patrols between 1868 and 1888, might seem out of place to anyone familiar with the adage that the Gulf in nineteenth and early twentieth century was a 'British lake'. ${ }^{4}$ Great Britain had, after all, been at the forefront of the global antislavery movement, had negotiated a series of treaties with local rulers and had embarked on a naval crusade for the express purpose of ending the slave trade from East Africa to Gulf. Viscount Palmerston, when Foreign Secretary in 1846 pledged that Great Britain was 'the main instrument in the Hands of Providence' to 'put an end to the African Slave Trade', and he urged the political agent for Muscat and Zanzibar to impress upon 'these Arabs' that it was 'in vain' for them 'to endeavour to resist the consummation of that which is written in the Book of Fate' and that they 'ought to bow to Superior Power, to leave off a pursuit which is doomed to annihilation'. ${ }^{5}$ In spite of nineteenth-century hyperbole, the suppression of the slave trade had by the end of the century yielded to other priorities. This paper seeks to situate the dilemma of slavery in the Gulf in the context of the British Persian Gulf Administration's conflicting commitments to antislavery and free markets.

\section{The Nature of the Dilemma}

Slavery posed a dilemma for the British in the Gulf: a conflict between the objectives of liberal politics and liberal economics. On one hand, the administration was committed by treaty and popular sentiment at home to the suppression of the slave trade. On the other hand it was committed to the maintenance of free trade and tranquillity of Gulf waters. These goals conflicted because the Gulf's two largest export products - pearls and dates - relied heavily on slave labour. Gulf officials feared that completely suppressing the slave trade and outlawing slavery as an institution would severely restrain production of those products in the Gulf, limit exports, reduce revenues, and consequently retard imports, thereby making the administration so unpopular as to make its rule untenable. The primary goal of the administration in the Gulf was always to protect the route to India by opposing the establishment of any potentially threatening forces in the Gulf. The goal of second importance wavered between the suppression of slavery and the protection and encouragement of free trade.

By the late nineteenth century, antislavery had taken a back seat to both free trade and the protection of India as a result of three factors. The first of these was the growing threat of imperial competition in the Gulf. The Gulf was too close to India for the British to tolerate the significant naval presence of any other imperial power. However, the Gulf was positioned at the confluence of empires and increasingly developed into a contested maritime 
space, particularly after the opening of the Suez Canal in 1869. As one British naval commander noted following a Turkish warship's entry into the Gulf in 1871, the opening of the Suez Canal had its 'shady side, and for the pre-eminence we have held in the Gulf since the decline of the Portuguese power, a very shady side'. While most European powers had little interest in the Gulf, he explained, 'for Russia on one side of this Gulf and Turkey on the other, there appear much attraction'. Russia, he suspected, sought an arrangement with Persia for access to a port on its coast, most likely Bandar Abbas, giving Russia access to a warm water port in place of the Black Sea access lost from the Crimean War. The Ottoman Empire, the commander suspected, had designs on unifying the Arabian Peninsula under its rule for the symbolic value to Muslims worldwide and to compensate for lost territory in Europe. With the opening of the Suez Canal, the Ottomans could easily send troops and supplies to Arabia by steamer and were beginning to reassert their control over the Eastern Arabian province of Hasa from Basra. 'I cannot help thinking that the Sultan and the Czar understand each other remarkably well', the commander continued. He suspected that the two empires were sending ships into the Gulf 'as a 'feeler' - just to see how far we shall take notice or object to this invasion of a sea in which for many years we have held undisputed sway ${ }^{*}{ }^{6}$

A second factor was the annexation of Zanzibar as a protectorate. With the declaration of the British protectorate at Zanzibar in 1890 , reports on the slave trade to the Gulf declined sharply, not because the trade itself had disappeared, but because publicity about the persistence of the slave trade would have prejudiced imperial interests. Great Britain had taken a leading role in the antislavery movement and was still in the process of negotiating its imperial claims in East Africa vis-à-vis Portugal, France, and Germany. The persistence of slavery within a British protectorate (as opposed to a sphere of influence) would have embarrassed the government, further inflamed antislavery activists in Britain, and reinforced Portuguese mistrust of British motives in East Africa. British equivocation on abolition was not limited to East Africa or the Gulf; similar behaviour can also be detected in India and northern Nigeria.?

A third and greater factor was the changing reality of the Gulf economy. Demand for labour in the Gulf, particularly young male labour, was on the increase in the last quarter of the nineteenth century and the first quarter of the twentieth century with the dramatic expansion of the Gulf pearl industry and date industry. The volume of dates imported into the United States, which came almost exclusively from Basra and Muscat, increased more than six-fold between 1894 and $1925 .^{\circ}$ The global market for pearls grew steadily from 1885 to 1906 , and then skyrocketed'between 1910 and 1914. The value of Bahrain's pearl exports alone increased five-fold between 1909 and 1913. In 1906, just before the biggest leap in global pearl prices, the value of pearl production in the Gulf was equal to that of all other areas of the world combined. ${ }^{9}$ A leading Parisian pearl merchant estimated that, at the peak of the pearl market, eighty percent of the natural pearls consumed in the West came from the Gulf. ${ }^{10}$ As a result of increased demand for labour in these sectors, the importation of slave labour, first from East Africa and later from Baluchistan and Persian Makran, had become a profitable enterprise. Young men were increasingly kidnapped and brought to the Gulf and put to work in the pearl fisheries and date plantations. The testimonies of manumitted slaves at the offices of the British consulate in Muscat, the Political Agent at Bahrain, and the Residency Agent at Sharjah from 1921 to 1940 are filled with stories of men who were kidnapped from East Africa as children and forced to work in the pearl banks when they reached maturity. ${ }^{11}$

\section{Symptoms of the Dilemma}

Symptoms of the confusion of British policy toward slavery in the Gulf were apparent at various levels, none more obvious than the actions of the Royal Navy. Naval patrols were instructed under an 1875 circular to avoid accepting fugitive slaves aboard British ships except under life-and-death circumstances. 'The broad rule to be observed', the circular explained, 'is that a fugitive Slave should not be permanently received on board any description of ship under the British flag, unless his life would be endangered if he were not allowed to come on board'. The reason for this, the statement continued, was that accepting fugitives in other cases would result in encouraging the breaking of the laws of the countries where slaves were 'legally owned'. The letter continued:

For it might happen, to take an extreme instance, that the whole slave portion of the crews of vessels engaged in the Pearl Fishery in the Persian Gulf might take refuge on board British Ships, and if free there, their masters would be entirely ruined, and the mistrust and hatred caused in their minds would be greatly prejudicial to British interests. ${ }^{12}$

This logic followed an incident a few years earlier when, during the pearling season of 1873 , an enslaved man who had been out diving for pearls near the island of Zairku, swam off from one of the seventy-three fishing boats lying near the HMS May Frere and begged protection. The First Assistant suggested that once the man had been admitted on board he was entitled to protection, so he allowed him to stay. As soon as word reached the captains of the pearling boats, they weighed anchor for fear of other slaves fleeing or retribution from the Royal Navy for having slaves among their crews. In debating the legality of the officer's judgment, Edward C. Ross, the Political Resident, conjectured that if commanders made a habit of accepting runaway slaves at the pearl banks, "where the diving was carried on almost entirely by domestic slaves, who if they found an opportunity might run off to a British vessel, a general feeling of consternation and disgust would be produced, and we should no longer be regarded as the friendly protectors of the maritime Arabs'. The Home Government agreed that if runaway slaves found refuge on British ships, then 'their masters would be entirely ruined', which would destroy British material interests by the mistrust and hatred which would be occasioned'. ${ }^{13}$ 
Even the Royal Navy's celebrated antislavery efforts in the Western Indian Ocean were ineffective and chronically under-funded. Since the East Indies Station, which after 1867 coordinated antislavery duties in the Indian Ocean, was required to have six ships around India at all times, the antislavery squadron rarely consisted of more than three regular ships to patrol 4,000 kilometres (2,500 miles) of coastline. ${ }^{14}$ When Admiral Cockburn entreated the Admiralty board in 1871 for more ships and resources for antislavery duties in the Indian Ocean, the Admiralty noted that 'the Treasury have positively decided not to sanction any increased charge for suppression of the slave trade at present, consequently no object appears gained by discussing what might be done with an increased force'. ${ }^{15}$

East India Station orders for 1877 urged captains to follow the letter of each antislavery treaty carefully and, while bearing in mind the importance of using 'the most zealous exertions' for putting an end to the slave trade, they were to 'observe the greatest care and vigilance not to exceed the provisions' of the treaties, and not to afford any foreign governments 'any just cause of complaint' for their actions. With regard to boarding dhows showing French flags, 'enquiry into any matter beyond her nationality is strictly forbidden', and special rules were to be followed since the 'boarding of Vessels flying the French Flag is almost invariably attended with some future litigation'. Furthermore, captains were to bear in mind that the 'right of visiting vessels suspected of fraudulently using the French Flag ceases altogether within a three miles' range of land', and it would be 'most discourteous and improper' to exercise this right when 'in sight of a French Flag' flying on the shore. ${ }^{16}$

In spite of ample evidence that French flags were being illegally used to protect slave traders, the Royal Navy continued to respect the sovereignty of the French flag until the British government challenged the French in the Permanent Court of Arbitration at the Hague in 1904. ${ }^{17}$ In 1863 a dhow with French papers was known to have shipped nearly 300 slaves from Kilwa in coastal East Africa to Shihr in the Hadhramaut while flying a French flag. ${ }^{18}$ In February 1871, when the HMS Columbine approached two dhows, one with a red (Arab) flag and the other with a French flag, the captain of the dhow with the red flag transferred the slaves he had aboard to the dhow with the French flag to avoid having them captured. ${ }^{19}$ The boatswain on the HMS Star recalled in the vessel's logbook, that during patrol the commander refused to board dhows which passed them flying the French flag off the coast of Brava, in southern Somalia, in November $1867 .^{20}$ In the $1880 \mathrm{~s}$ a Swahili observer summarized the situation as follows:

Persons who trade in slaves often use the flag of the French to ship them because the British are not permitted to enter any ship that sails under the French flag. This is the reason why some Muslims seek the protection of the French nation. And if they want to hoist the French flag they pay for it. They pay an annual flag fee [...] Among those who hoist the French flag are many Arabs who are called Wasuri. They frequently ship slaves with their vessels. ${ }^{21}$
Two dhows arrested by the HMS Sphinx in 1896 were found to contain '200 negroes, of whom the greater part must have been slaves', and in June 1900 Indian residents of Sur reported that 1,000 enslaved Africans had been imported that season, of which 560 were estimated to have been brought by dhows flying the French flag. The British Consul at Muscat quizzed the 79 slaves who sought manumission at the Muscat consulate between April 1901 and April 1902, and found that forty-nine of them were unaware what flag they had been brought under and fourteen of the remaining eighteen said they had been brought under French colours. ${ }^{22}$

Further symptoms of the conflicted approach to slavery could be found in the attitudes of administration officials toward the institution of slavery. Administrators believed that slavery was a natural part of Arab life - sanctioned by Islam, and that Arabs were naturally lazy, unwilling to perform manual labour and, therefore, dependant on slave labour. Slavery was regarded as an ingrained element of the Arab psyche rather than a response to economic pressures (as in the Atlantic). Consequently, the administration believed that the institution of slavery would not be given up without violent enforcement or the passage of many years and the advancement of Arabs to higher levels of 'civilisation'. Admiral Heath believed the slave trade supplied 'a want which has not been left unsatisfied for many centuries past, a want which, sanctioned by the religion of the country, has grown almost into an instinct'. ${ }^{3}$ Captain Boyes, the Senior Naval Officer in the Gulf, remarked in 1929 that, "It may be taken as a general principle that Arabs will not do any work of a "laboring" kind and from time immemorial have had slaves to do it for them'. He explained that, 'To attempt to compel Arabia, in its present state of development, to give up slavery could perhaps be compared with attempting to compel Glasgow to give up the use of mechanical apparatus and whisky', ${ }^{24}$

Additionally, administrators viewed Gulf slavery as a tolerable institution because they believed slavery took a particularly mild form in the Gulf that could even be beneficial to the enslaved. Several reports reasoned that slavery was completely different from Atlantic plantation slavery - labour was described as undemanding, cruelty was judged to be minimal, and most slaves appeared to enjoy a quality of life equal to or better than that many members of the free population of similar class. Some administrators also believed that freed slaves would be incapable of surviving on their own, most having been kidnapped as children or born into slavery and not having known any other state of life. ${ }^{25}$ Thus, when political expediency demanded, officials could easily turn a blind eye to slavery and the slave trade. When a newly imported Baluchi slave begged for manumission aboard the HMS Lupin at Sharjah in 1927, the commander decided to yield to the request of the Sheikh of Sharjah to return the man to his master. He reasoned that, in view of the R.A.F. negotiations with the sheikh about the establishment of an airfield at Sharjah, the issue of slavery was better left alone. ${ }^{26}$

Another symptom of the dilemma presented by slavery was the toleration of the behaviour of the British Residency Agent at Sharjah, as cases like that of the Ethiopian man, Surūr, described above, demonstrated. The agency, a 
post held by a local Persian resident, had the unenviable position of being the sole representative of British authority on the Arab coast between Muscat and Bahrain. As such, the agent was authorized to issue manumission certificates to slaves who sought freedom based on the cruelty of their masters, but he also had to maintain his position among the residents of Sharjah, including the Sheikh of Sharjah, the titular head of the Qawāsim tribe. For his efforts the agent received a small monthly allowance and some additional benefits. ${ }^{27}$ Among enslaved Africans the Sharjah agent was notorious for accepting bribes from slave owners and returning slaves to their masters. His reputation was such that runaway slaves preferred to walk from Dubai to Muscat, more than 350 kilometres (220 miles), than to seek the protection of the agent in neighbouring Sharjah. One runaway, Thāni bin Miftah, who sought freedom from the Political Agent at Muscat in 1928 declared that he did not go to the Residency Agent at Sharjah 'because whenever a slave takes refuge with him he takes money from the master and returns the slave to him'. ${ }^{28}$

When runaways reached Muscat from the Trucial Coast, the Political Agent generally wrote to the Residency Agent at Sharjah seeking confirmation of the runaway's story. More often than not, if the runaway was a diver, the agent replied that he was not in fact a slave, but a free diver who was indebted to a diving captain or pearl merchant, and requested the Muscat agent to send the man back to Sharjah for further investigation. The Political Agent rarely did so. In the case of Thäni bin Miftah, the Sharjah agent claimed that he was in fact a free diver who was indebted to his näkhuda (captain) for 600 rupees, and he requested Thanni be returned to Sharjah. The Political Resident refused, arguing that Thāni had been in Muscat for three months while he case was being considered, and the näkhudā, 'if he really considered that his claim was against the negro and not against his alleged 'master' would without doubt have journeyed to Muscat and lodged his complaint'. He concluded that it would be 'unwise' to send him back to Sharjah, since 'it is difficult to find justice there and it is realized that the position of the Residency Agent is such that he more often than not tries to fall in with the wishes of the powerful Shaikhs and the Nakhodas' ${ }^{29}$

In May 1933 a Baluchi man named Ismail swam half a mile from shore to reach the HMS Bideford which was lying off the coast of Sharjah. Once aboard the sloop, the man explained to the commander that he was the slave of a local pearl merchant and dhow owner who sent him to dive for pearls each season and treated him cruelly. Ismail had run away the year before to the Residency Agent at Sharjah, who had imprisoned him for three days until his master came and paid fifty rupees. The master then took him home, beat him, chained him for four days without food, and then sent him to the pear banks in his dhow. The commander took pity on Ismail and decided to hold him until the next day when the Residency Agent was scheduled to come aboard and could verify his story. The agent denied ever having seen ismail before, but the commander observed that when Ismail was confronted with the agent "he displayed the most abject terror and stated that he would rather I cut his throat on the spot than I should send him ashore in his charge. He said it would be a repetition of the last time'.$^{30}$ Hector Boyes, the Senior Naval Officer of the Persian Gulf Division, once remarked that the Sharjah agent, 'gives us a sop occasionally of a slave just to keep things quiet. If he did more, they all agree his life would not be worth five minutes purchase, and also he has to live and make money'."1

\section{Addressing the Dilemma}

Faced with new political and economic realities in the Gulf in the late nineteenth century, the British Persian Gulf Administration drifted toward toleration of the institution of slavery on the Arabian coast, while encouraging the already prevalent Muslim practice of manumission by granting official manumission certificates. As for the slave trade, the administration attempted to expand and clarify legal rights to search vessels at sea, and dealt sporadically with suspected slave traders and the local rulers nominally responsible for them by using performative punishment and military display. The ineffectiveness of these policies was evidenced by the continuation of both the slave trade and the institution of slavery well into the twentieth century, and would only face serious challenge in the 1930 s.

The first element of British policy toward slavery was manumission. While no serious attempt was made to prohibit slavery on the coast, the British Persian Gulf Administration encouraged manumission by granting manumission certificates modelled on the letters of certification issued by qãdhis throughout Arabia on the manumission of slaves. Manumission was frequently granted by slave owners in the Gulf through regular Muslim legal channels. ${ }^{32}$ The British manumission certificates were modelled on the language of equivalent Islamic legal documents and were highly valued by those who possessed them. The certificates included the name of the freed person, certification of freedom in English and Arabic, and an official seal The certificates were granted through the office of the resident at the request of the Political Agents of Muscat or Bahrain or the Residency Agent in Sharjah. Runaway slaves presented themselves at the agencies or consulates and gave an official statement, generally in the form of answers to a list of or the agent himself. When the testimony was completed it was usually translated, typed, and sent to the Political Resident for approval. In the case of pearl divers - the most common fugitives seeking manumission - the Resident often sought verification from local authorities that the diver was not a freeman with large debts who was seeking manumission to escape his indebtedness. As free divers were constantly indebted to their captains or pearl merchants, the process could often take several months to complete. ${ }^{3}$

Another element of British action against the slave trade was its legal effort to expand the ability to search foreign vessels at sea. As mentioned previously, the administration was increasingly aware of the extensive use of the French flag to protect the slave traders from search by British cruisers In 1904, the issue was brought before the Permanent Court of Arbitration at the Hague, which issued a decision in August 1905. Although ostensibly 
about slave trading, the British case claimed that, in granting flags to dhow owners from Sur, French authorities undermined the Sultan of Muscat's independence, which France had pledged to mutually protect under a treaty with Great Britain in 1862, because the mariners who flew French flags claimed exemptions from the sultan's taxes. ${ }^{34}$ The court was charged with determining the legality of granting French flags to Omani subjects and what rights were attached to flying the French flag if allowed. The court concluded that since France had agreed to the terms of the General Act of the Brussels Conference of 1890 , which stipulated that signatory powers could only grant the use of their flags to vessels which were owned or fitted out by either 'subjects of or persons protected by the power whose flag they claim to fly', France could not grant its flag to Omani dhow owners who were not French 'protégés' after 2 January 1892, the date France ratified the treaty. To answer the more difficult question of who could constitute protegés, the court looked to precedent in the case of Ottoman capitulations, which following the Ottoman law of Sefer 23, 1280 (August 1863), were limited to specific groups of people, including foreign subjects and those grandfathered into protection by having ancestors who were protected by foreign powers prior to the treaty. The court ruled that the cases of Muscat and the Ottoman Empire were too dissimilar to allow the French to establish Omani protégés based their having ancestors or relatives who were protected by them as was the case in Turkey. 'The protégés of the Christian powers in Turkey [werel of race, nationality and religion different from their Ottoman rulers', the court explained, "whilst the inhabitants of Sur and other Muscat people who might apply for French flags are in all these respects entirely in the same condition as the other subjects of the Sultan of Muscat.' Therefore the court concluded that France was not entitled to authorize Omani vessels to fly the French flag after 1892, when it ratified the Brussels Act, and those who had been granted French flags prior to that date could not pass on that privilege to their descendents. The case marked a partial victory for Great Britain. ${ }^{35}$

\section{Shock and Awe: Military Display as Theatre}

In addressing the slave trade, the administration resorted to forms of performative punishment, often through what is commonly called 'gunboat diplomacy' ${ }^{36}$ In his seminal work on the history of the penal system, Michel Foucault distinguished between what he called 'discipline blockade', which places criminality and punishment 'on the edges of the social body', and 'discipline mechanism', characterized by panopticism, which spreads surveillance throughout the social body and incorporates the individual subject into the normalizing regime. The degree of control which Foucault called 'discipline-mechanism', which the British achieved elsewhere in the Middle East, as Timothy Mitchell has shown for Egypt and Toby Dodge has shown for Iraq, was not achieved in the Gulf states. ${ }^{37}$ Rather. British imperial authority in the Gulf was limited to what Foucault called 'discipline-blockade' exceptional discipline aimed at negative functions: 'arresting evil, breaking communications, suspending time', characterized by public spectacle, theatre, and bodily experience. ${ }^{38}$ When the British Navy engaged in 'gunboat diplomacy' in the Gulf, it intended to maximize display to arrest the slave trade by creating fear of potential bodily consequences of the contravention of treaties.

In the Gulf, military display took two forms: destructive - involving naval bombardments typical of gunboat diplomacy elsewhere in the Empire, destroying forts, watchtowers, and ships - and demonstrative - involving the personal display of naval grandeur to notables and the public through harbour visits and walking tours of naval vessels. Destructive and demonstra. tive displays of power were calculated to evince 'shock' and 'awe' respectively. When destructive force was employed, it was calculated to maximize display, through the destruction of a symbolic structure, such as a fort or watchtower, or the vehicle for criminal activity, such as a slaving dhow, in as dramatic a fashion as possible.

A key element of destructive display in the Gulf was the use of Hale's war rockets. The English inventor, William Hale, improved upon the Congreve rockets used between the Napoleonic Wars and the Crimean War (and immortalized in the American national anthem by Francis Scott Key) by dispensing with the Congreve's wooden stabilizing sticks, improving the accuracy by rifling the launch tubes so that the rockets spun in the air, and devising an all-metal construction. By 1867 the British army and navy had formally adopted Hale's rockets and began using them in colonial campaigns. The navy first demonstrated the utility of Hale's rockets in the Abyssinian campaign of 1868 , during which more than 200 were fired. In the army's official reports on the campaign, the rockets were credited with 'astonishing' the enemy with their 'roar' and inducing Tewodros to exclaim, 'What a terrible weapon - who can fight against it?'39 In the Royal Navy's antislavery campaign in the Indian Ocean from 1868 to 1888 , Hale's rockets became standard issue. When Captain Malcolm suggested his plan for improving the antislavery patrols in East Africa by creating a single depot ship to be based at Zanzibar supplemented by American-style yachts as patrol boats, he requested the new ship be equipped with two twenty-four pounder Hale's war rocket tubes and noted that 'the supply of ammunition, especially rockets to the guard ship, should be very large'.40

Describing a Hale's rocket in action against a slaving dhow off the coast of Oman, Lt. C.M. Gilbert Cooper wrote, 'Few who have seen the war rocket fired, forget the sensation they experience when hearing it for the first time, and evidently the shriek and the flame and the smoke of it disconcerted them all not a little, and checked all further resistance'. ${ }^{41}$ Recalling his experiences as a junior officer on the HMS Briton while patrolling for slave traders in the Mozambique Channel in 1873, G. Keith Gordon described the effectiveness of rockets after residents of a coastal town speared a member of the boat's crew.

Quite an array of men armed mostly with spears and long swords, and a few old muskets, danced about the gate, as if they wanted to stop our entry. They evidently did not realize our strength or power, 
thinking we were going to land. As they were at least five or six times numerically superior to us, it would not have done for us to have attempted such a thing. So getting as close as the depth of the water allowed, we shelled the village with the pinnace's gun, and the cutter gave them a few war rockets, setting the place on fire, and frightening them more than the gun did.

These war rockets are much on the same principle as the ordinary sky rocket, but the composition is enclosed in an iron cylinder, four inches in diameter and about two feet long with a shell in the head. They are fired from a long eight foot tube fixed over the side of the boat. When they strike anything square they drop to the ground, but if the charge is still burning, they start off again from the ground in the direction they are pointing, sometimes even back to starting point; or they will jump about the place like a fire cracker, until the composition is expended, when the shell at the head explodes, scattering the iron everywhere [...]. About ten minutes of this work soon dispersed the crowd $[\ldots]^{42}$

The logic behind such imprecise weapons was to maximize display, rather than cause death or injury. In this instance, the rockets killed only one member of the opposing party and injured no one else. With the crowd scattered, the Briton's boats effected a landing, destroyed the palm trees and crops, and filled the wells. 'One has to be severe in dealing with these natives', Gordon explained, 'for leniency makes them think we are afraid of them, and leads to more trouble. The lesson they got had a very salutary effect for a long time, as the news of the affair soon spread up and down the coast'. ${ }^{43}$

In the Gulf, display, whether with rockets, guns or fire, was intended to have the same effect: to maximize shock value with a minimum loss of life, and allow the power of rumour to circulate news of the display. Most often, these goals were achieved through the bombardment of symbolic structures such as a particular sheikh's fort or watchtowers. Such actions were contemplated whenever local rulers were deemed to be particularly uncooperative, especially on the issue of the slave trade. In May 1921, the Sheikh of Ajman, Humaid bin Abdulaziz, was accused of re-enslaving a manumitted slave who had been given a government manumission certificate by the Political Resident in Bushire four years earlier. Humaid reportedly tore up the certificate and reclaimed the slave as his own. When the Political Resident received word of the sheikh's defiance, he visited Ajman with two gunboats and demanded he come aboard and pay a fine of 1,000 rupees within two hours or face the destruction of his watchtowers. When the sheikh was deemed 'defiant and recalcitrant' and failed to pay the fine, the HMS Cyclamen fired and demolished the towers. The fine was brought the same night. ${ }^{*}$ Similarly, on the opposite side of the Mussendam peninsula at Fujairah, Sheikh Hamad bin Abdullah was accused of purchasing a kidnapped Baluchi girl and giving 'insolent replies' to the Political Resident. When the Resident, Col. Prideaux, visited Fujairah aboard the HMS Lawrence, the sheikh refused his demand to come aboard. Thus, in April
1925, HMS Triad and HMS Cyclamen bombarded the fort of Fujairah and recovered a fine of 1,500 rupees from the sheikh. ${ }^{45}$

A more pressing case involving slavery arose in Sharjah, when the British Residency Agent reported the following immediately after British warships left Sharjah in January 1931:

After nightfall when I was asleep in my house suddenly a hue and cry was heard in the vicinity of the house and the women folk informed me that Abdur Rahman bin Muhammad accompanied by about a hundred men, inhabitants of Hirah, had collected in front of the gate of our house, in our bazaars and on the sea shore in front of our house and that there existed the Shaikh of Shargah and his fighting men and they demanded the slaves who had taken refuge with us and that they were trying to enter the house. ${ }^{46}$

Residency Agent Isa, had taken in six runaway slaves, and had held them in his compound overnight, as was the official procedure, until he could record their testimonies and forward the information, if necessary, to Bushire for adjudication by the Political Resident. Resenting the interference of the agent in local matters, and perhaps fearing the further flight of valuable pearl divers and a subsequent loss of income in an increasingly depressed pearl market, the Sheikh of Sharjah and the crowd demanded the return of the slaves. lsa reported that one of the local residents convinced the sheikh to desist 'because the Agency is a British Government house' and 'it would bring them repentance in the end', but while the crowd eventually dissipated, in the following days the agent feared for his life. ${ }^{47}$ The Political Resident suggested to the Government of India that the sheikh either be deposed in favour of his uncle, who 'favors the British connection', or be forced to pay a fine of 2,000 rupees and surrender 100 rifles within four days on penalty of the destruction of his towers outside of town. The resident thought that the defence towers, 'situated as they are outside and clear of the village, would be suitable objectives for the first lesson'. Their 'destruction', he wrote, 'while being spectacular and within sight and sound of Sharjah, should not be attended by any loss of life'. Alternatively, his fort 'comes under excellent observation from a certain anchorage and is an easy target. No other buildings should be damaged by fire directed at this fort'. ${ }^{4}$.

On the morning of 11 March 1931, demands were made and the inhabitants were warned that the bombardment would begin at midnight if the sheikh did not pay the required fine. At $1 \mathrm{pm}$, the sheikh arrived on the beach with 1,200 rupees and sixty rifles. Residency Agent Isa was sent ashore to tell him that unless he brought the full amount he would not be received. At 9:30 pm he returned with the full fine and 100 old model rifles, but six of the rifles did not fit the stipulation that they be breach-loading and serviceable, so the sheikh was ordered to replace them by midnight. An hour before the deadline he replaced the final six rifles, and destruction was averted. Afterward, Col. Briscoe, the Political Resident, reflected that 'the promptness with which action was taken undoubtedly impressed the population' ${ }^{49}$

However, the shelling of forts and the levelling of watchtowers had limited 
impact on groups with no attachment to fixed structures near the shore. During the short rule of Azan bin Qais over Muscat in the $1860 \mathrm{~s}$, the salafist Mutawwa movement represented one such group. A merchant recounted a conversation between the head of the garrison at the gate of Muscat and three followers of the Mutawwa movement. One of the men explained:

The Gunboat has been brought under our Fort to frighten us. We are afraid of nobody. If twenty Gunboats came we should not be afraid. Should any calamity overtake us, we know we possess nothing but the clothes on our back and our words. We know we possess in Muscat no property no houses no furniture no gardens. Muscat is not our country nor the country of our fathers, nor the country of Seyid Azan's father. We shall at once quit the place and bolt. ${ }^{50}$

The threat of force was predominantly applied to rulers who feared the loss of fixed structures near shorelines, and those who depended on British support to maintain their rule. Others could be influenced by the destruction of mobile property.

In November 1882, the commander of the HMS Woodlark captured five vessels which were wanted for plundering in the pearl fisheries. The captain had the five boats anchored near the man-of-war and burnt them, waiting until after dark, 'the blaze being distinctly seen far up and down the coast'. He had four more boats burnt on shore the following morning at dawn, and remarked that the burning 'appears to have made a great impression' ${ }^{51}$ In December 1928, the Residency Agent of Sharjah reported to the visiting Senior Naval Officer in the Persian Gulf that a dhow in Dubai harbour had been carrying slaves, two women and two boys. The commander-in-chief elected to destroy the abandoned dhow publicly in order to impress upon Sheikh of Dubai his responsibility to suppress the slave trade in his territory. With a large crowd assembled on the shore, and the Sheikhs of Dubai, Sharjah, Ajman and Umm Al-Qaiwain on hand, the HMS Lupin towed the dhow a safe distance out to sea and set it ablaze, 'having previously placed a guncotton charge in her which produced an impressive explosion'.52 The following year, when a similar operation was contemplated in Abu Dhabi, the Senior Naval Officer recalled that there was 'not doubt' that the destruction of the dhow in Dubai 'was a good object lesson to the coast and the day chosen was advantageous as, owing to the presence of the commander-in-chief many notables from along the coast were assembled in the port'. ${ }^{53}$

The second form of display used in the Gulf, demonstrative display, was designed to secure compliance by creating a sense of awe among local inhabitants or increasing the prestige of the local ruler with whom the power was associated. Beginning in 1900 , when a Russian gunboat visited a number of ports in the Gulf, the British government made a policy of upstaging foreign visitors with cruises through the Gulf of the largest British men-of-war (which were too large to enter many Gulf harbours). Remarking on this phenomenon in 1905, the author of the Government of India's Precis on Naval Arrangements in the Persian Gulf, 1862-1905 explained:
In recent years, a great deal of importance has been attached by forelgn nations competing with the British in the Persian Gulf to making display of large men-of-war on its shores. However poorly off these nations might be at home in the number of such ships, their display is calculated to make a deep impression upon the natives, who know nothing of the naval strength of the several powers in Europe except what they see with their own eyes. Hence, the British Government in order to counteract the impression produced by the visits of foreign cruisers in the Gulf, have taken opportunities to dispatch some of their large vessels to the Gulf. ${ }^{54}$

In December 1901, the Russian cruiser Varyag entered the Gulf and visited Muscat, Bandar Abbas, Lingah, Bushire, Muhammerah, Basrah and Kuwait, and 'made as much display as possible'. Concerned that the Varyag's 'sight and movements made a deep impression on the people', Col. Kimball, the Political Resident in the Persian Gulf, sought to have a larger British man-ofwar on its way to China stop by Muscat and the Gulf. In June 1902, the 11,000-ton HMS Amphitrite called at Muscat, and showed its flag at the major Omani ports of Sur, Seeb and Barka, before calling at Bahrain, Bushire, Kuwait, the Trucial Coast, and Khor Fakan. It was the biggest European naval vessel to have ever visited the Gulf. At each port, the captain opened the ship to sightseers and made "liberal exercise of the search light to impress the natives'. ${ }^{.5}$ At Muscat, the captain gave the Sultan and his son, brother, and entourage a tour of the ship and took them out to observe target practice. Captain Windham recalled in a letter to Admiralty that the firing was good and evidently created an impression' ${ }^{56}$ He reflected that his call at the Omani ports in Batinah would 'undoubtedly, strengthen the Sultan's hands in these places as exaggerated reports as to size, armament, and crew, quickly spread inland".5?

The following year, the even more impressive HMS Argonaut, accompanied by a flotilla of six men-of-war, conveyed Viceroy Curzon on his tour of the Gulf intended to demonstrate British supremacy to inhabitants of the major port cities. At Sharjah, Curzon held one of his trademark durbars aboard the Argonaut, in which local notables were invited to sit in chairs arranged neatly in rows on a fine assortment of Oriental carpets beneath a canopy of flags in front of an elevated stage, upon which Curzon sat in a gilded throne flanked by uniformed officers while gun turrets loomed in the background. These conspicuous displays of pomp and power were calculated to convey a looming threat of force, although, in reality, that force could rarely be applied.

\section{Epilogue}

Around the time Suñr made his escape back to Ethiopla, two external factors had begun to direct the British administration's gradual policy shift toward greater effort for abolition. Left to themselves, the administration would likely have continued their existing policy of largely ignoring slavery, 
but new circumstances required a shift in policy. ${ }^{59}$ The first factor came in the form of the collapse of pearl prices in the wake of the introduction of Japanese cultured pearls and spread of the global depression of 1929, and the second came in the form of pressure from the League of Nations beginning in 1932 . The global market for pearls had begun to decline shortly after the First World War, largely as the result of the mass marketing of Kokichi Mikimoto's cultured pearls in Europe and the United States. ${ }^{60}$ While in 1906 the value of natural pearls from the Gulf was equal the production of all other areas of the world combined, the world pearl market of the 1920 s was dominated by Japanese cultured pearls. The long pearl necklaces, fashion icons of the 'roaring twenties' in the United States, were largely of Japanese rather than Arabian manufacture. The value of Gulf pearl exports had fallen to nineteenth-century levels by 1924 , and declined steadily until the start of the global depression. Exports collapsed to new depths by 1932 and never recovered. ${ }^{61}$ With the collapse of pearl prices, the Gulf pearling industry suffered a dramatic shock. Merchants and lenders who had invested heavily in slave labour, could now no longer afford to maintain their enslaved divers, and increasingly set them free, reducing the risk to the administration of becoming unpopular for addressing the issue of slavery.

The second factor came in the form of pressure from the League of Nations, particularly after the forming of the Advisory Committee of Experts on Slavery in 1933. As early as 1929 , the administration has been pressured to prepare reports on the status of slavery in the Gulf, which produced a great deal of fear about negative international attention. ${ }^{62}$ The Senior Naval Officer in the Gulf expressed his worry that if Britain entered into a dispute with Persia, 'the Persian Government may turn on us and point to the mass of slavery on the Arabian shores and, if referred to the League of Nations, would bring out the existing state of affairs'. The whole issue was such a vast one, he said, 'it looks as if the Government will have to decide as to whether it is going to allow treaties to be openly flouted. As far as I can judge, to take action will raise an uproar; but at the same time is Great Britain to tell the world that they are afraid to put it down?'63

The British representative to the permanent advisory committee, Sir George Maxwell, a former chief secretary of the Malay states, adopted a strategy of pressuring the administration for straight answers about slavery in the Gulf. As a result, the administration, which was not eager to draw international attention to either the shaky legal claim it held on the Gulf states or the status of slavery, was forced to produce a number of reports on the issue and reconsider its position. During the first session of the committee, Maxwell was embarrassed by the vague answers the administration supplied and was frustrated by their lack of cooperation. ${ }^{64}$ He reported that when the French member of the committee heard the administration's reply about British sloops not having captured any slave traders recently, he retorted, "If 1 do not shoot tigers in my jungles, 1 do not say that that proves that there are no tigers'. ${ }^{65}$

In the 1930s the British Persian Gulf Administration was forced to reconsider its policy of largely ignoring slavery. However, before substantive changes were made on the issue, the dilemma of slavery was complicated by new pressures arising from early oil concessions and the growth of the petroleum industry. The dilemma of slavery, which pitted the objectives of liberal politics against liberal economics for more than half a century, would wait until after the Second World War for resolution. ${ }^{66}$

\section{Bibliography of Works Cited}

Primary Sources

Bombay Correspondence, 1840-1884 (AA 3), AA 3/18, Zanzibar National Archives (ZNA), Zanzibar, Tanzania.

Zanzibar, Tanzania.
British Parliamentary Papers: Slave Trade (Shannon, 1969).

Field, Admiral Sir Arthur Mostyn, Papers (FIE/43), National Maritime Museurn, Greenwich, United Kingdom (hereafter NMM).

Foreign Office Correspondence, 1838-1890 (AA 1), AA 1/2, AA 1/10, Zanzibar National Archives (ZNA), Zanzibar, Tanzania.

Gilbert-Cooper, Lt. C. M. Papers (BGY/G/5), NNM.

India Office Records (IOR), Political and Secret Department Records (L/PS) L/PS/12/4091, L/PS/20/C246, L/PS/20/C248B, British Library, London.

India Office Records (IOR), Records of the British Residency and Agencies in the Persian Gulf
(R/PS/ India Office Records (IOR), Records of the British Residency and Agencies in the Persian Gulf
(R/15) R/15/1/204, R/15/1/208, R/15/1/209, R/15/1/216, R/15/1/225, R/15/1/226, $\mathrm{R} / 15 / 1 / 552, \mathrm{R} / 15 / 6 / 3$, British Library, London.

Logbook of HMS Star kept by John G. Lynch, 1866-1869 (MSS.Brit.Emp.s.536), Bodleian Library of Commonwealth and African Studies at Rhodes House (RHO), Oxford University. Milne, Sir Alexander, Papers (MLN/160), NMM.

Muscat Dhows Arbitration in the Permanent Court of Arbitration at the Hague, Grant of the French Flag to Muscat Dhows: The Counter-Case on Behalf of the Government of His Britannic Majesty (London: Foreign Office, 1905)

Persian Gulf Administration Reports: 1873-1947 (Gerrards Cross, 1986).

Persian Gulf Trade Reports: 1905-1940 (Gerrards Cross, 1987).

Records of the Admiralty (ADM), ADM 1/6093, ADM 1/6190, ADM 1/6261, ADM 1/6230, ADM $1 / 6412$, ADM 1/6622, National Archives (PRO), London.

Records of the Foreign Office (FO), FO 54/34, National Archives (PRO), London,

United States Department of Agriculture, Yearbook of the United States Department of Agriculture, 1898-1919 (Washington, DC: G.P.O., 1895-1920).

United States Department of Agriculture, Yearbook, 1920-1922 (Washington: G.P.O., 1921-

1923).
United States Department of Agriculture, Agriculture Yearbook, 1923-1925 (Washington: G.P.O., 1924-1926)

Books

Adelson, Roger, London and the invention of the Middle East: Money, Power, and War, 19021922 (New Haven, 1995).

Anscombe, Frederick F., The Ottoman Gulf: The Creation of Kuwait, Saudi Arabia, and Qatar (New York, 1997).

Bose, Sugata, A Hundred Horizons: The Indian Ocean in the Age of Global Empire (Cambridge, 2006).
2006).

Bromber, Katrin, ed., The Jurisdiction of the Sultan of Zanzibar and the Subjects of Foreign Nations (Würzburg, 2001).

Busch, Briton Cooper, Britain and the Persian Gulf, 1894-1914 (Berkeley, 1967).

Cable, James, Gunboat Diplomacy. 1919-1979: Political Applications of Limited Naval Fonce (New York, 1981).

Clarence-Smith, William Gervase, Islam and the Abolition of Slavery (London, 2006). 
Cooper, Frederick, From Slaves to Squatters: Plantation Labour and Agriculture in Zanzibar and Coastal Kenya, 1890-1925 (Portsmouth, 1997)

Dodge, Toby, Inventing Iraq: The Fallure of Nation Building and a History Denied (New York, 2003).

Eunson, Robert, The Pearl King: The Story of the Fabulous Mikimoto (Tokyo, 1964).

Foucault, Michel, Discipline and Punish: The Birth of the Prison, 2nd ed. (New York, 1995).

Kunz, George Frederick and Charles Hugh Stevenson, The Book of the Pearl. The History. Art Science and industry of the Queen of Gems (New York, 1908).

Lloyd, Christopher, The Navy and the Slave Trade: The Suppression of the African Slave Trade in the Nineteenth Century (London, 1949).

Lovejoy, Paul E., Transformations in Slavery: A History of Slavery in Africa (Cambridge, 1983) -, and Jan S. Hogendorn, Slow Death for Slavery: The Course of Abolition in Northern Nigeria, 1897-1936 (New York, 1993).

Miers, Suzanne, Slavery in the Twentieth Century: The Evolution of a Global Problem (Lanham, 2003).

Mitchell, Timothy, Colonizing Egypt (Berkeley, 1988)

Panikkar, K.M., India and the Indian Ocean: An Essay on the Influence of Sea Power on Indian History (Bombay, 1951).

Rosenthal, Leonard, The Pearl Hunter: An Autobiography (New York, 1952).

Winter, Frank H., The First Golden Age of Rocketry: Congreve and Hale Rockets of the Nineteenth Century (Washington, DC, 1990).

\section{Articles/Essays}

Bondarevsky, Grigori L., 'Turning Persian Gulf into a British Lake: British Domination in the Indian Ocean in the Nineteenth and Twentieth Centuries', in Satish Chandra, ed., The Indian Ocean: Explorations in History, Commerce and Politics (Newbury Park, 1987), 317-325.

Chatterjee, Indrani, 'Abolition by Denial? Slavery in South Asia after 1843', in Gwyn Campbell, ed, Abolition and its Aftermath in Indian Ocean Africa and Asia (New York, 2005), 150-168. Gallagher, John, 'Nationalisms and the Crisis of Empire, 1919-1922', Modern Asian Studles $15 / 3$ (1981), 355-368.

- 'Great Britain v. France', American Journal of International Law 2/4 (Oct. 1908), 921-928. Lewis, William Roger, 'The British Withdrawal from the Gulf, 1967-71', The Journal of Imperial E. Commonwealth History 31/1 (2003), 83-108.

Mandel, Robert, 'The Effectiveness of Gunboat Diplomacy', International Studies Quarterly 30/1 (March 1986), 59-76.

Onley, James, 'Britain's Native Agents in Arabia and Persia in the Nineteenth Century', Comparative Studies of South Asia, Africa and the Middle East 24/1 (2004), 129-135.

Sheriff, Abdul, 'The Slave Trade and its Fallout in the Persian Gulf', in Campbell, ed., Abolition, 103-119.

Steven Cohan, 'Victorian Power', NOVEL: A Forum on Fiction 22/3 (Spring 1989), 350-353. Westlake, John, 'The Muscat Dhows', Law Quarterly Review 23 (1907), 83-87.

Zinkin. Maurice, 'The Commonwealth and Britain East of Suez', International Affairs 42/2 (April 1966), 207-218.

\section{Notes}

* Matthew S. Hopper is Assistant Professor in the Department of History at California Polytechnic State University (Cal Poly), Polytechic State (Iniversity (Cal Poly), San Luis Obispo. His research focuses on the cultural and economic legacy of the African diaspora in the Indian Ocean. Research for this article was funded in

part by grants from the Social Science Research Council and the Fulbright-Hays Program. I am grateful to Professors Ed ward Alpers, Lauren Benton, and James Gelvin for comments on portions of earlier drafts of this paper. He can be reached at mshopperacalpoly.edu.
5 Viscount Palmerston, Foreign Secretary,
1 W.L. Bond to Colonel G. Loch, 27 Dec. 1933, IOR R/15/1/209.

2 Throughout this paper 'Persian Gulf Administration' refers to the Persian Gulf Political Residency and all political agents, residency agents, consuls, viceconsuls, native agents, and other officers under the Political Resident, Persian Gulf, at Bushire.

3 'Memorandum on the use of the French Flag by Suri and Muscat Dhows', enclosure 2 in Marquess of Landsdowne to Sir E. Monson, 16 April 1902, IOR R/15/ 1/552. Greville, Acting British Consul (Beira), 'Report on the Capture, Trial, and Sentence of Certain Muscat Slavers by Sentence of Certain Muscat Slavers by the Portuguese Authorities at Mozam -
bique under the Provision of the General Act of the Brussels Conference, and of Section 162 of the Portuguese Penal Code', 17 Oct. 1903, FO 54/34.

4 Bondarevsky, 'Turning Persian Gulf', passim: Lewis, 'British Withdrawal', 86; Adelson, London and the Invention, 7. Alternatively, the Indian Ocean as a whole has been described as a 'British lake' in: Panikkar, India and the Indian, passim; Gallagher, 'Nationalisms and the Crisis', 358; Zinkin, 'Commonwealth and Britain', 214. to Col. Atkins Hamerton, Political Agent, Zanzibar, 18 Dec. 1846. ZNA AA $1 / 2$.

6 Commander F.P. Doughty (HMS Magpie) to Rear Admiral Cockburn, Commanderin-Chief, East Indies Station, 29 Nov. 1871, PRO ADM 1/6230. On Ottoman expansion in the Gulf see: Anscombe, The Ottoman Gulf On the expansion of Russian French and German interests in the Gulf see: Busch, Britain and the Persian Gulf.

7 Cooper, From Slaves to Squatters, 24-68; Miers, Slavery. 18-25, 32-38, 47-51 Lovejoy, Transformations in Slavery, 260268. On India see: Chatterjee, 'Abolition by Denial', 150-168. For Nigeria see: Lovejoy, Slow Death for Slavery. For abolition in the Gulf see Sherff, "The Slave Trade', 103-119; Clarence-Smith, islam Trade', 103-119; Clarence-Smith,

11 See for example the statement of Marqāo bin Sa'ad, aged about 35 years, recorded at Bahrain, 3 May 1927, lOR R/15/1/204 and numerous other cases in files $R / 15 / 1 / 204$ through $R / 15 / 1 / 224$ in the R/15/1204 Office

12 Circular No. 33, Robert Hall, Admiralty to all Commanders-in-Chief, Captains, Commanders, and Commanding Officers of Her Majesty's Ships and Vessels. 31 July 1875 , NMM MLN/160.

13 J.S. Saldanha, 'Precis on the Slave Trade in the Gulf of Oman and the Persian Gult, 1873-1905', 63-64, 1OR L/PS/20/C246.

14 Testimony of Rear Admiral Arthur Cum ming, examined 11 March 1876 , 'Minutes of Evidence Taken Before the Royal Commission on Fugitive Slaves', reprinted in British Parliamentary Papers: Slave Trade 92, 309; Lloyd, Navy and the Slave Trade, 283-284.

15 Admiral Cockburn to Secretary of Admiralty, 17 July 1871 , PRO ADM 1/6190.

16 'Station Orders for Her Majesty's Ships and Royal Naval Establishments on the East India Station, 1877', 54, 56-57, PRO ADM $1 / 6412$.

17 Muscat Dhows Arbitration, passim Westlake, 'Muscat Dhows', 83-87; 'Great Britain v. France', 921-928.

18 Robert Lambert Playfair to Earl Russell 30 Dec. 1863, ZNA AA 3/18.

19 Sir Bartle Frere to Earl Granville, 24 March 1873, in Letterbook: Mission to Zanzibar, 1872-73, 245-255, ZNA AA $1 / 10$

20 Lynch, entry for 6 Nov, 1867, RHO Logbook of HMS Star.

21 Bromber, Junisdiction of the Sultan of Zanzibar, 25

22 'Memorandum on the Use of the French Flag by Suri and Muscat Dhows', enclosure 2 in Marquess of Landsdowne to Sir sure 2 in Marquess of Landsdowne to Sir
E. Monson, 16 April 1902, IOR R/15/1/ E. M.

23 L.G. Heath, Commander in Chief, East Indies, to Secretary of Admiralty, 1 March 1869, PRO ADM 1/6093.

24 Captain Hector Boyes, Senior Naval Officer, Persian Gulf Division (HMS Thiad) to Commander in Chief, East Indies Station, 12 Sept. 1929, IOR L/PS/12 4091 .

United States Department of Agriculture 1898-1919; Yearbook, 1920-1922; Agriculture Yearbook, 1923-1925.

9 Kunz, The Book of the Pearl, 80.

10 Rosenthal, The Pearl Hunter, 66.
25 'Notes on the Slave Trade by Wazir Thomas, Aug. 1929', (P. 7418/29), IOR L/PS/12/4091; Miers, Slavery, 164-168. 
26 Commander Hugh F. Curry (HMS Lupin) to Senior Maval Officer, Persian Gulf Division (23 May 1927), IOR R/15/1/208

27 Onley, 'Britain's Native Agents', 129-135

28 Statement of Thāni bin Miftah ('Negro') born in Sharjah, aged about 55 years, 12 Oct. 1928, IOR R/15/1/216.

29 Residency Agent, Sharjah, to Political Resident, Persian Gulf, 12 Dec. 1928 Secretary to Political Resident, Persian Gulf, to Political Agent, Muscat, $18 \mathrm{Feb}$ 1929, IOR R/15/1/216.

30 E.C. Dennison (HMS Bideford) to Political Resident, Persian Gulf, 22 May 1933, IOR R/15/1/209.

31 Captain Hector Boyes, Senior Naval Officer, (HMS Triad), to C.C.J. Barrett, 24 Aug. 1929, IOR R/15/1/225.

32 See Clarence-Smith, Islam and the Abolition of Slavery, 16-21, 114-118.

33 Miers, Slavery, 164-168.

34 Muscat Dhows Arbitration, passim.

35 Westlake, 'Muscat Dhows', 83-87; 'Great Britain v. France', 921-928.

36 Classic works on gunboat diplomacy include: Cable, Gunboat Diplomacy, and Mandel. 'The Effectiveness of Gunboat Diplomacy', 59-76.

37 Mitchell, Colonizing Egypt, 95-127 Dodge, Inventing Iraq, 131-156.

38 Foucault, Discipline and Punish, 3-31, 195.228; Cohan, 'Victorian Power', 350353.

39 Winter, First Golden Age of Rocketry, 293-297, 215-224.

40 Captain Malcolm to Admiralty Board 1 July 1873 , PRO ADM $1 / 6261$.

41 Lt. C.M. Gilbert-Cooper, 'Capture of a Slave Dhow: Or the Vulture and Its Prey Times of India, n.d., c. 1872, NMM BGY $\mathrm{G} / 5$.

42 Memoirs of $\mathrm{G}$. Keith Gordon, junior offcer, HMS Briton, MS 79/176, NMM FIE 43.

43 bid.

44 Secretary's notes, 'Punishment of the Sheikh of Ajman', IOR R/15/1/216.

45 Secretary's notes, 'Punishment of the Sheikh of Fujairah', JOR R/15/1/216.

46 Residency Agent, Sharjah, to Captain R. G. Alban, Undersecretary to Political Resident in the Persian Gulf, 4 Feb. 1931,
IOR R/15/1/208.

47 Ibid.

48 Telegram, Political Resident, Persian Gulf to Government of India, New Delhi, Mo. T39, 17 Feb. 1931: Resume of Affairs at Sharjah No 32/295, HMS Hastings at Shat 11 Feb 1931, IOR R/15/1/208.

Shayj, 11 Feb. 1931, IOR R/15/

LL. Col. Hugh Vincent Biscoe, Political Resident, Persian Gulf, to Forelgn Secretary to the Government of India, New Delhi 20 March 1931, IOR R/15/1/208.

50 Herbert Frederick Disbrowe to Secretary to Government to Bombay, 27 Oct. 1869 , IOR R/15/6/3.

51 Thomas P.W. Nesham, Commander (HMS Arab) and Senior Naval Officer, Persian Gulf Division, 24 Oct. 1882, PRO ADM $1 / 6622$.

52 Hector Boyes, Senior Naval Officer, Persian Gulf, to Commander in Chief, East Indies Station, 19 Dec. 1928, IOR L/PS/12/4091.

53 Senior Naval Officer, Persian Gulf, to Political Resident, Persian Gulf, 24 June 1929, IOR R/15/1/225.

54 Precis on Naval Arrangements in the Persian Gulf, 1862-1905', IOR L/PS/20/ C248B.

55 Ibid.

56 Captain Windham to Secretary of Admiralty, 30 June 1902, IOR R/15/1/ 552.

58 Adelson, London and the Invention of the Middle East, 47.49: Bose. A Hundred Horizons, 36-40.

Horizons, $36-40$.
Miers, Slavery, 166 .

59 Miers, Slavery, 166.

61 Persian Gulf Administration Annual Reports, 1873-1905, and Persian Gul Trade Statistics, 1905-1944

62 Meirs, Slavery, 216-232, 263-267.

63 Captain Hector Boyes, Senior Maval Officer, Persian Gulf Division (HMS Triad) to Cyril Charles Johnson Barrett, Acting Political Resident, Persian Gulf, Aug. 24, 1929, IOR R/15/1/225.

64 Meirs, Slavery, 216-232, 263-267.

65 Sir George Maxwell to J.C. Walton, Esq., India Office, 30 July 1936, IOR R/15/1/ 226.

66 Miers, Slavery, 306-313 


\section{Itinerario}

volume $\mathrm{xxx}$ (2006) number 3

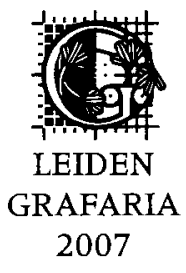


Itinerario is published by the Institute for the History of European Expansion (IGEER), Department of History, Leiden University, PO Box 9515, 2300 RA Leiden, The Netherlands

e-mail: ltinerario@let.leidenuniv.nl - website: http://www.itinerario.nl

Itinerario is the official journal of the Forum on European Expansion and Global Interaction, FEEGI, in the USA

website: http://www.feegi.org

Editor-in-Chief: Hendrik E. Niemeijer

Book Review Editor: Markus Vink (markus.vink@fredonia.edu)

Editors: Lennart Bes, Annelieke Dirks, David Henley, Wim Klooster, Gijs Kruijtzer Peter Mancall, Lincoln Paine, Damian Pargas, Frans-Paul van der Putten, Alicia Schrikker, Werner Thomas

Editorial Assistant: Karuna Sharma

Advisory Board:

- Prof. Dr L. Blussé, Leiden University, The Netherlands (East and Southeast Asia)

- Prof. Dr H.W. van den Doel, Leiden University, The Metherlands (Modern

Imperialism and Decolonisation)

- Prof. Dr P.C. Emmer, Leiden University, The Netherlands (Atlantic World)

- Prof. Dr H. Giliomee, Professor Emeritus in Stellenbosch, South Africa (Africa)

- Prof. Dr Om Prakash, Delhi School of Economics, India (South Asia)

Submission of articles: Itinerario welcomes submissions dealing with all aspects related to European Expansian and Global Interaction in Africa, the Americas, Asia, Australia, and Europe. Articles may be sent directly to: itinerario@let.leidenuniv.nl For more information about the Itinerario style sheet and procedure of peer refereeing and acceptance: http://www.itinerario.nl.

Subscriptions and Financial Administration outside the U.S.A.: please contact Marijke van Wissen-van Staden at m.c.e.wissen@let.leidenuniv.nl. Address for subscriptions: Itinerario, Dept. of History, Leiden University, PO Box 9515, 2300 RA Leiden, The Netherlands. Fax +31.71.527-2652; Tel. +31.71.527-2767.

Subscriptions and Financial Administration in the U.S.A., Mexico and Canada: Itinerario, c/o John Carter Brown Library, Box 1894, Providence, Rhode Island 02912, U.S.A.

Subscription fees for 2006: $€ 49$ or US\$ 62.00 (individual) and $€ 63$ or US\$ 87.00 (institutional). FEEGl-members sending a check to the John Carter Brown Library will be charged only US\$ 51.00. Single-issue price: $€ 18$ or US\$20.00.

All amounts include VAT. VAT registration Number NL 001935549B01. In case of payment by MasterCard or VISA-Card, no bank charges are due. To cancel subscriptions, please inform by e-mail or letter before 1 January.

\section{(C) 2006 Itinerario}

No part of this publication may be reproduced or transmitted in any form or by any means, electronic of mechanical, including photocopy, recording, or any information storage and retrieval system, without permission from the copyright owner.

Cover lay out: Anton Feddema, Amsterdam

Illustration: by courtesy of the National History Museum, London; Herbarium of Paul Hermann, Vol. 5, lcones, f. $307,38 \times 52.5 \mathrm{~cm}$

ISSN 0165-1153

\section{Letter from the Editors}

This special issue of Itinerario celebrates the thirtieth anniversary of our journal and event that was marked by and coincided with the international, interdisciplinary conference, 'Culture and Commerce in the Indian Ocean', hosted at Leiden University, September 25-27, 2006, and co-sponsored by the University of Technology in Sydney, Australia.

This number opens with an interview by Damian Pargas of Pieter Emmer (Leiden University), a leading expert on the history of European expansion and migration history in the Atlantic world, who has been intimately involved with Itinerario from its very inception. The origins of the Forum 'Colliding Geographies and the Dilemma of Imperial Authority' can be traced back to a panel at the 120th Annual Meeting of the American Historical Association in Philadelphia in January 2006. Preceded by a note from the guest editor, Linda M. Rupert (University of North Carolina at Greensboro), the forum consists of five contributions: Jennifer L. Anderson (New York University) explores the environmental realities and problems of imperial authority in the Bay of Honduras; Lauren Benton (New York University) discuss the spatial histories of empire; Lisa Ford (Columbia University) investigates empire and order on the colonial frontiers of Georgia and New South Wales; Matthew S. Hopper (University of California, Los Angeles) surveys imperialism and the dilemma of slavery in eastern Arabia and the Persian Gulf between 1873 and 1939; and Linda Rupert concludes with an investigation of contraband trade and the shaping of colonial societies in Curaçao and the Tierra Firme.

The Editors would like to thank Markus Vink (State University of New York at Fredonia) for arranging the book reviews and review articles. The two review articles in this issue are: Ronald Jay Morgan (Abilene Christian University-in-Oxford), 'How The Other Half Actually Lives: More Historical Perspectives On Non-Elite Religious and Political Culture in Colonial Mexico'; and Matthew J. Shaw (The British Library), 'Slave Revolts in the Revolutionary Caribbean and the Atlantic World'.

We would also like to use this opportunity to thank our readers and contributors for their continued support of and submissions to Itinerario throughout these past three decades. We hope that we can count on your continued support and urge you to encourage others to join as members and contributors. We look forward to providing this unique platform for the foreseeable and more distant future.

The Editors 